\title{
Considerations to some forms of the verb a fi: sum and sunt
}

\author{
Gheorghe Chivu* \\ Faculty of Letters, University of Bucharest, Str. Edgar Quinet 5-7, Sector 1, 010017 Bucharest, Romania \\ Romanian Academy, Calea Victoriei 125, Sector 1, 010071 Bucharest, Romania
}

\section{Article info}

History:

Received June 4, 2018

Accepted June 9, 2018

Published October 7, 2018

Keywords:

Romanian literary norm

literary norm

cultured verbal forms

sum

sunt

\begin{abstract}
The history of the verbal forms sum and sunt, introduced into the literary writing by the Transylvanian Latinist School, reveals a winding process in the elaboration of certain cultured norms proper to the modern literary Romanian. Not at all linear, this process was concurrently influenced by two, often divergent, tendencies that were active from the end of the $18^{\text {th }}$ century up to the beginning of the $20^{\text {th }}$ century: the use of some cultured forms, borrowed from Latin or created according to Latin patterns; and the revitalization of certain linguistic forms with regional diffusion.

Initially proposed as literary pronunciations, the two verbal forms were soon adopted and used as etymological graphic forms that corresponded to $\operatorname{sim}$ and suntu from certain conservative patois. During the second half of the $19^{\text {th }}$ century (sum), and during the first decades of the $20^{\text {th }}$ century (sunt), the two graphic forms became orthoepic norms as well, due to the phonological tradition of the Romanian writing.
\end{abstract}

I. The Transylvanian School, the well-known Enlightenment movement, was concerned, for the first time in the history of the Romanian written culture, with the standardization of the modern literary language, in a programmatic way, through representative works of orthography, grammar and vocabulary.

First of all, there was the remarkable effort towards the creation of an alphabet proper to the requirements of the Romanian writing, through the elaboration and, consequently, the imposition of an orthographic system based on the Latin alphabet. This new alphabet ought to have offered the Romanian language a "coat" that could render its Latin origin evident, and could also achieve its unity in writing, a type of unity impossible to obtain while the Cyrillic alphabet-which was maintaining the territorial separation of the literary writing-was in use. Through the phonetic aspect that they were promoting, the Transylvanian scholars aimed also at the standardization of the cultivated pronunciation, demanding, e.g., the avoidance of the central vowels and the elimination of some of the consonantal alternations, in order to preserve, unmodified, the radical of certain words, and, consequently, to highlight their morphological structure. Through the systematic renewal of the literary vocabulary-a continuous struggle against the shortcomings of a language that needed assume the statute of an elevated instrument for the diffusion of the modern secular culture-, the scholars promoted, beside numerous Latin and Romance neologisms, the so-called "root words" (words inherited from Latin), and the words that were derived from them and that were formed according to Latin patterns and with Latin affixes.

Being of a lesser importance in proving the Latinity of our language, a series of morphological norms promoted by the Transylvanian scholars referred to bringing up to date-with the Romance perspective in view-certain forms specific to the old Romanian (e.g., the use of the long infinitive with verbal function; see Chivu, 2015, p. 183-1902), to the elimination of some flexional homonymies (like the one created by the formal identity of the $3^{\text {rd }}$ and $6^{\text {th }}$ persons of the imperfect; see Gheție $\&$ Teodorescu, 1965, p. 87-101;

\footnotetext{
*Email address: gheorghe.chivu@gmail.com.

${ }^{1}$ The expression belongs to Iorgovici (1799/1979, p. 79 passim).

${ }^{2}$ For examples and bibliography, see also Nedelcu (2013).
} 
1966, p. 175-183), to embracing certain Latino-Romance models (the classes of adjectives and adverbs ended in -e, see Avram, 1992a, p. 234-250, and the participial forms in -ind and -ind, see Avram, 1992b, p. 205-217), or to the imposition of some verbal forms of cultured type (like sum and sunt).

The history of the two aforementioned verbal forms, graphic or/and of pronunciation, reveals a winding process in the elaboration of certain cultured norms proper to the modern literary Romanian, a process indissolubly linked to the Transylvanian Latinist movement. Not at all linear, this process was concurrently influenced by two tendencies, not always convergent, present and highly active in the Romanian literary writing, from the end of the $18^{\text {th }}$ century up to the beginning of the $20^{\text {th }}$ century: the use of some cultured forms, borrowed from Latin or created according to Latin patterns; and the revitalization of certain linguistic forms with regional diffusion.

II.1. The authors of the thesaurus Dicționarului tezaur al limbii române [The Dictionary of the Romanian Language], the only lexicographic work intended to the general public that records sum, write in a lapidary manner, without any illustration, that "the forms sum [I am], sunt [they are], suntem [we are], sunteți [you are, pl.] were introduced into the literary language by the Latinist school" (DA 1934, p. 113, s.v. $f i)$, the observation being almost exactly reproduced in Micul dicționar academic [The Small Academic Dictionary] (MDA 2002, p. 410, s.v. fi).

By saying so, Sextil Pușcariu was referring, of course, to the main grammar work that had illustrated the academic Latinism, Gramateca limbei române [The Grammar of the Romanian Language] (Cipariu, $1869 / 1987,1876 / 1992)$, where sum had been recommended as the basic form of the "substantive verb" a fi [to be], both in the section reserved to the morphological description of the language, and in the section with examples concerning the syntax (Cipariu, 1869/1987, p. 274; 1876/1992, p. 19, 21, 71, 83, 206, 214). Nevertheless, Sextil Pușcariu knew, undoubtedly, that the same form had appeared in some previous works of the scholar from Blaj (Cipariu, 1854; 1855; 1866).

Timotei Cipariu accepted and used a linguistic form that had been constantly appearing in the writings of the Transylvanian Latinists, since the end of the $18^{\text {th }}$ century ${ }^{3}$.

In 1794, sum (scris $\mathbf{c} 8 \mathbf{M}$ ) was used twice in a belletristic text currently called Istoria amerii [The Story of Love], from a Romanian Calendariul ['almanac'] printed with Cyrillic letters in Vienna ${ }^{4}$ : "eu sum numai o fată ignorantă", "eu sum secură" (p. 33) ["I'm only an ignorant girl", "I am sure"]. Paul Iorgovici-who is now believed to be the translator of Istoria amerii (Ursu, 1963, p. 283-291; Chivu, 2002a, p. 90) and the maker of Calendariu -would use the same form, written with Cyrillic letters too: "sum, esci, este; sum, es, est; sein; sânt, ești, este" (Iorgovici, 1799/1979, p. 69).

Petru Maior (1819) used sum as well, in 1819, in the column written with Latin letters and etymological orthography of his programmatic Dialog pentru începutul limbei română [Dialogue About the Beginning of the Romanian Language], a text that was first printed in Buda, as an appendix to Orthographia Romana sive Latino-Valachica and then, unmodified (with the same paging even), in Lexiconul romanesclatinesc-unguresc-nemțesc [The Romanian-Latin-Hungarian-German Lexicon, i.e. The Buda Lexicon] from 1825: "sum (sủnt) incredentiatu" (p. 54, 58) ["I am sure"]. (In 1819, in the column written with Cyrillic letters, süm appeared as ckm.) In 1825, the Lexicon itself registered süm as an equivalent to sint, s.v. escu: "Escu. Macedo-Valachice, süm. V<ide> sünt" (p. 206) ${ }^{6}$. And one year later, Ioan Alexi (1826)

\footnotetext{
${ }^{3}$ In what follows here, the passages excerpted from sources written with Cyrillic letters or with the so-called "alphabet of transition" are interpretatively transcribed; while those from sources written with Latin letters and in the etymological manner are reproduced as such; we do this in order to prevent any anticipation on the pronunciation of the linguistic forms sum and sunt.

${ }^{4}$ For the text's transcription, see Chivu (2002a, p. 91-98).

${ }^{5}$ For the modern edition of the cited fragment, see Fugariu (1983, p. 608, 609) and Maior (1976, p. 303, 306).

${ }^{6}$ In the entry sunt, a fi, fostu of the Lexicon, sum is again used in the explanation of the first meaning of the title-word: " 1 )

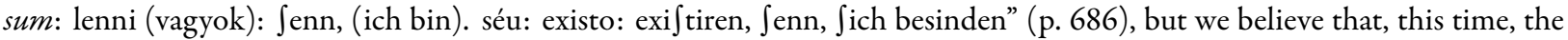
form belongs to Latin. (In reproducing the fragment, we've preserved the orthographic signs and the punctuation from the
} 
put the form sum before sunt in the indicative-present paradigm of the verb a fi: "jo sum, sunt, ego sum vel escu" (p. 81).

The form sum (spelled sum, from 1819 on, in many a text written with etymological alphabet), which was not at all scarce in the programmatic works by scholars who belonged to the Transylvanian Enlightenment ${ }^{7}$, made its way into various texts that were being printed in Transylvania, but also into some of the schoolbooks printed in Moldavia and Wallachia. In these regions, beside sum (or sum) -in manuals

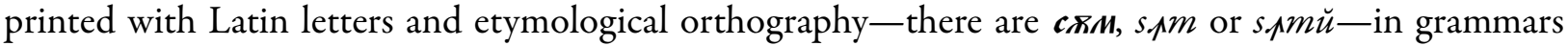
written with Cyrillic letters or with the "alphabet of transition".

Thus, Samuil Micu used the form sum in Cartea cătră cler și popor [The Book for Clergy and People] (Micu, 1824, p. 10). Ioan Alexi believed and wrote in his Gramatica Daco-Romana sive Valachica (Alexi, 1826) that sum is a basic form in the conjugation of the verb a fi: "io sum vel sủnt" (p. 77; also, p. 81). During the same year, Nicolao Maniu Montan used the same form in constructing several expressions in Romanian, written with Latin letters, in Orthoepia Latina, Latino-Valachica, Hungarica, Germanica et Serbo-Valachica (Sibiu; Maniu Montan, 1826): "Eu sủm Domnul Dumned̦eul tủu” [I am your Lord God] (p. 34), and "acum sủm cu o d̦i mai a própe de mórte" [now I am one day closer to death] (p. 36). In his Gramatica românească [The Romanian Grammar], Gh. Seulescu placed sîm (written cxm) after sint, in the series of the $1^{\text {st }}$ person singular indicative-present forms of the verb a fi: "sânt și [and] sâm, îs, escu” (Seulescu, 1833, p. 102). In 1848, Petru Maller Câmpeanu, a Transylvanian author who had settled down in Iași ${ }^{8}$, included sim (written, like in Seulescu's grammar, $\mathbf{c} \mathbf{x}$ ), as a recommended form: “eu sâm (sânt)" [I am] (Maller Câmpeanu, 1848, p. 93). In the same year, in his Rudimentele gramaticei române [The Fundamentals of the Romanian Grammar] (a manual intended for the beginners in the acquisition of Romanian), Ion Codru Drăgușanu - the Transylvanian self-taught who had been a teacher in Ploiești for a while-made the observation, while commenting on "studiele limbistice" [the linguistic notes] of an enigmatic Latinist philologist, Ğ.M.F. (?), that the form sim (spelled s.pmü) belongs to the "classical" paradigm of the verb a $f$ (Codru, 1848, p. 69). Nicolau Bălășescu, born in the southern part of Transylvania and better known as metropolitan Nifon, wrote in his Gramatica română [The Romanian Grammar] printed in 1848, mainly for the seminarians, in Sibiu: "românii în vorbire întrebuințează des îsủ și sủ (sum), în loc de sânt; ba am auzit esc, esci, este, estem, esteți, estü" [when they speak, the Romanians often use $\hat{\imath} s \hat{u}$ and $\operatorname{su}(s u m)$, instead of sînt; I've even heard esc, esci, este, estem, esteți, estủ] (Bălășescu, 1848, p. 105) ${ }^{9}$; and two years later, in Elemente de Grammatică română pentru școlarii începători [Elements of Romanian Grammar for the Beginning Pupils], printed in Bucharest, he recommended the form sîm

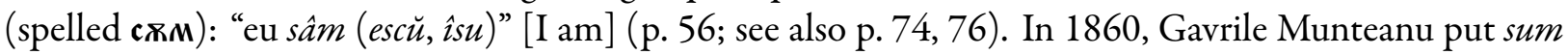
alongside of sunt, sủ and escü (Munteanu, 1860, p. 48), in Partea etimologică [The Etymological Part] (i.e., morphological) of a Gramatica române [Romanian Grammar], printed in Braşov and intended "pentru clasile gimnasiali inferiori" [for the inferior gymnasium forms].

The form sum, spelled as such in texts authored by Transylvanian Latinists and by other Transylvanians or Moldavians who had been influenced by the linguistic concepts of the first-mentioned thinkers, had a quite limited echo in the Romanian texts of the second half of the $19^{\text {th }}$ century.

Timotei Cipariu, who had had recommended it (see supra) in the first academic Grammar of the Romanian Language (Bucharest, 1869), used to avoid it in his non-linguistic writings ${ }^{10}$; and A.T. Laurian

\footnotetext{
Lexicon.)

${ }^{7}$ The use of sum in the Viennese Calendariu from 1794 is only a seeming exception to this assertation, since, by publishing the translation called Istoria amerii, Paul Iorgovici aimed at popularizing a new type of belletristic texts, and also at illustrating a particular attitude towards the form of a literary piece of writing. For all of these, see Chivu (2002b, p. 149-158).

${ }^{8}$ Petru Maller had printed, in Buda, in 1832, Grammatică hungarico-valachică [A Hungarian-Wallachian Grammar] for schools (Maller, 1832).

${ }^{9}$ The entire fragment, like the book itself, is written with Cyrillic letters, with the exception of sum. Therefore, the author might have used it here to indicate not a Romanian flexional form, but a Latin equivalent (or the etymon?) for (i) sủ.

${ }^{10}$ The form sum - which is not used in Jurnal [Diary] (written, nevertheless, in 1836), in Scrisorildin Italia [Letters from Italy] (1852), and in Memorii [Memoirs] (1855) (see Cipariu, 1972)-appears once in a discourse prepared in 1863, for the
} 
and I.C. Massim did not select it, as a recommendable form (s.v. fire), in Dicționarul limbei române-the first project of an academic dictionary, printed between 1871 and 1877 (Laurian \& Massim, 1871).

However, the Latinist scholars and their followers (mainly jurists, public functionaries and journalists) ${ }^{11}$ resorted to sum (maybe even in academic conversations), since B.P. Hasdeu-a categorical opponent of the Latinists—used it in Duduca Mamuca [Miss Mamuca] (as well as in Micuţa [The Little One], a variant of the former) and in Orthonerozia sau Trei crai de la răsărit [The Orthostupidity or Three Kings from the East $]^{12}$, with a stylistic intention, apparently. Mocking, seemingly, a certain manner of speech ${ }^{13}$, Hasdeu introduced sum in the speaking of the main character of the story, a law student, and in that of Vladimir Aleșchin-Uho, a journalist: "sum prea rumen la față” [I am too ruddy in the cheeks] (p. 154, 227), "Nu sum în stare! Nu sum frumos!" [I am not able! I am not handsome!] (p. 197) ${ }^{14}$. It is also used in the play Orthonerozia, to characterize Numa Consule (a character built to mock the Latinism) through language; the form appears in the letter that this character sends to Hagi-Pană: "eu nu sum emptore, io sum procu" [I am not a buyer, I am a suitor] (Hasdeu, 2003, p. 223), "Io, Peregrine Pannonie, sum antica classicitate, Roma avitica” [I, Peregrine Pannonie, am the classical antiquity, the forefathers' Rome] (p. 243).

The less educated Transylvanians too might have used the form sum, under the influence of the school and due to the prestige enjoyed there by the Latinist movement, since Teofil Frâncu and George Candrea registered it, in 1888, in the language of the people living in the Hălmagiu Valley ("Verbul a fi se aude în următoarele forme: $\hat{\imath}$, sum, sâmt, sânt, escŭ, estŭ; aceste două din urmă se aud în comuna Țebea, iar sum se aude pe valea Hălmagiului, pe cînd $m i$-'s se aude numai în părțile inferioare ale Zărandului” [The verb a $f i$ is used with the following forms: $\hat{s}$, sum, simt, sint, escŭu, estŭu; one can hear the last two in Țebea, and sum, in the Hălmagiu Valley, while mi-'s is heard exclusively in the lower parts of Zărand], Frâncu \& Candrea, 1888, p. 78); V.E. Ardelean introduced it, in 1903, in a poem called Marşul redactorilor "Tribunii” [The March of the Tribuna's Editors], written right after the periodical had been established in Sibiu: "sum agitator" [I am an agitator ${ }^{15}$.

II.2. The aforementioned data confirm the validity of Sextil Pușcariu’s observation, from 1934: sum was a morphological norm of scholarly nature, introduced into the Romanian literary language by some of the scholars who belonged to the Latinist movement, at the end of the $18^{\text {th }}$ century. (This norm should not be confused with sum, seldom used, and, again, only by the Latinists ${ }^{16}$, during the middle decades of the $19^{\text {th }}$ century, as a result of the "rehabilitation" and of the etymological spelling of sem, pronounced săm-the old form of the $1^{\text {st }}$ person, plural, indicative, of the same verb a fi.)

Registered for the first time in texts printed with Cyrillic letters, in which the phonological principle was dominant ${ }^{17}$, sum (spelled $\mathbf{c} 8 \mathrm{M}$ ) was corresponding, undoubtedly, around 1800, to an actual orthoepic norm, naturally identical with the pronunciation of the Latin form it proceeded from ${ }^{18}$. From 1819 till

Dieta of Sibiu: “io nu sum atât de comunist..." [I am not much of a communist...] (Cipariu, 1984, p. 141).

${ }^{11} \mathrm{~A}$ thorough examination of the administrative and juridical texts, as well as of the periodicals that were issued during the second half of the $19^{\text {th }}$ century may reveal further information about the use of the verbal form sum, since the two aforementioned domains (the justice and the administration) were heavily influenced by Latinism.

${ }^{12}$ We refer to Ion Șeulean's edition (Hasdeu, 1973), and to the edition made by Stancu Ilin and I. Oprișan (Hasdeu, 2003).

${ }^{13}$ In Duduca Mamuca, Hasdeu (1973) makes a direct reference to Timotei Cipariu, in a fragment attributed to Toderiță N.N.: "Voiești oare, cetitoriule, ca să te iubească sexul sau, cum zice d-l Cipar, sepsul frumos?" [Would you like, dear reader, to be loved by the female sex, or, as Mr. Cipar puts it, seps?] (p. 127).

${ }^{14}$ For other occurrences of sum, see p. 155, 156, 157, 162, 184, 185, 188, 191, 195, 197, 199, 208, 211, 215, $216,230$.

${ }^{15}$ This piece of information has been offered to us by Gavril Scridon; the entire text of the poem was intended to appear, as a note, in an edition of G. Coșbuc's works, an edition that should have been published in 1990, in Chișinău.

${ }^{16}$ See, e.g., the occurrence of sum in 1842, in Laurian (2002, p. 164), and in a letter by Cipariu (1972, p. 133).

${ }^{17}$ For the exceptions to the principle, see Chivu (2000b, p. 100-105).

${ }^{18}$ See Chivu (2000a, p. 434-435). The form sum is used, in fact, by Paul Iorgovici only in the case of the $1^{\text {st }}$ person singular, indicative present. . 
the abandoning of the etymologism as the dominant orthographic principle governing the Romanian writing with Latin letters, sum, with its graphic variant süm, corresponded to sim / sim/ in pronunciation. (Those who used the graphic form sum/sum, and had a knowledge, for sure, of the form c $8 \mathrm{~m}$ that had been introduced by Paul Iorgovici, interpreted the latter, most probably, in the etymological spirit.) That sum was to be pronounced / sim/ was first indicated by the graphic form čsm, present in the Cyrillic column of Dialogulpentru începutul limbei română (p. 54, 58), and was confirmed by various grammars printed with Cyrillic letters or in the alphabet of transition, during the first half of the 19th century, in Moldavia and

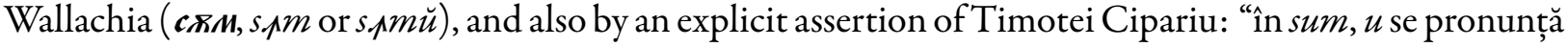
oscur, ca $\boldsymbol{x}$ " [in sum, $u$ is pronounced close, like $\boldsymbol{\pi}$; /it/, n.n., G.C.] (Cipariu, 1854, p. 148; 1876/1992; $1869 / 1987$, p. 46). Under the influence of the writing-almost normal in the Romanian culture, where the Cyrillic writing, governed by the phonological principle, had had a long tradition - the pronunciation sum /sum/ (attested in Paul Iorgovici's texts) reappeared, after 1860, in the speech of some scholars, more or less close to the Latinism ${ }^{19}$, and also (if the information given by Teofil Frâncu and George Candrea be true $\left.^{20}\right)$, in the speech of people in the Hălmagiu Valley.

With a history that covers more than a century, and with a winding evolution (concerning its spelling and pronunciation), sum - a cultured norm that had enjoyed a limited echo even in the linguistics-like works of the Latinists-practically vanished from the literary language at the beginning of the $20^{\text {th }}$ century.

The alternation between sum and sim in Transylvanian texts and the exclusive presence of sim in grammars published in Moldavia and Wallachia ${ }^{21}$ show-apart from the differences between the etymological and the phonological (with Cyrillic letters) method of writing, and apart from a possible internal evolution (sum - a morphological borrowing from Latin - might have been pronounced $/ \mathrm{sim} / \mathrm{in}$ the works of the Latinists through phonetic "Romanianizing") — that, at the beginning of the modern Romanian literary language, there was a strong attempt to revitalize certain forms that were considered to be "classic", closer to Latin ${ }^{22}$ ), and that had been registered by the old texts, and by the more conservative Dacoromanian dialects ${ }^{23}$.

The thinkers of the Transylvanian School knew sim, the form of the $1^{\text {st }}$ person singular, indicative present, from the Banatian patois ${ }^{24}$, from some of the Transylvanian patois and from the Aromanian dialect ${ }^{25}$. Timotei Cipariu too made the observation that the same form "încă tot se mai aude în gura poporului din Transilvania pe alocurea" [can still be heard in the people's speech, here and there, in Transylvania] (Cipariu, 1866, p. 141) ${ }^{26}$. And Gh. Săulescu-although he might have used it, in his Gramatica [Grammar] from 1833, under the influence of Petru Maller Câmpeanu-probably met sìm in old texts written

\footnotetext{
${ }^{19}$ The occurrences of sum in Duduca Mamuca (and Micuţa), and Orthonerozia may be, in spite of the ironical intention of the author, an argument for our statement. See also Cipariu (1869/1987, p. 275): "Persoana 1 sing., deși se pronunță în două moduri [sum, -su], e tot numai o formă sum, lat. sum, cu diferență că aici - $m$ finale latin se pronunță au nu se pronunță. ... Sum însă astăzi se aude mai rar și cu $x$ în loc de $u$..." [The $1^{\text {st }}$ person singular, although pronounced in two different ways [sum, -su], represents the same form, actually, sum, Lat. sum, with the difference that the Latin $-m$ is or is not pronounced. ... However, nowadays one can seldom hear sum with $\mathrm{x}$ instead of $u \ldots .$.$] .$

${ }^{20} \mathrm{H}$. Tiktin doubts the truthfulness of the idea that sum exists in the speech of common people, since he puts a question mark next to the example he has excerpted from Frâncu \& Candrea's monography (1888). See Tiktin (1906, p. 624, s.v. fi).

${ }^{21}$ The linguistic texts published in Wallachia, with sîm, were written by authors of Transylvanian origin.

${ }^{22}$ For this hypothesis, see Chivu (2000a, p. 434-435), p. 434-435.

${ }^{23}$ On this matter, see Gheție (1967, p. 221-223).

${ }^{24}$ Most likely, Petru Maior did not know about the existence of sim in Anonymus Caransebesiensis (see Chivu, 2008, p. 117), since this text would be discovered by B.P. Hasdeu, in Budapest, in 1871, and the first excerpts from it (accidentally, without the entry word sém - sum) would be published in 1891 (see Hasdeu, 1891, p. 1-48). Cf. Ivănescu (1980, p. 628), where the author says that the sum used by Petru Maior is a Banatian dialectal particularity. (Actually, G. Ivănescu reiterates here an idea he first expressed in Ivănescu (1944, p. 131-132).)

${ }^{25}$ See Lexiconul de la Buda, s.v. escu, where sum is held as "macedo-valachice".

${ }^{26}$ The form sîm, from simt in syntactic phonetics, was registered for the $3^{\text {rd }}$ person plural, indicative present, in central Transylvania (see ALR 1972: h./map 2157).
} 
in the north-eastern corner of the country ${ }^{27}$.

In Romanian, the form sim represented, actually, the result of two different phonetic evolutions: in some Dacoromanian patois and in Aromanian, sîm had appeared under a South-Slavic influence ${ }^{28}$; while sim from certain northern patois and from the old Romanian texts was a phonetic variant of $\operatorname{simt}<\operatorname{sint}$ ). However, Petru Maior, as well as Gh. Seulescu believed that $\operatorname{sim}$ (for the $1^{\text {st }}$ person singular, indicative present) was a continuer of the Latin form sum. Timotei Cipariu wrote, in fact, in his Elemente de limb $\breve{a}$ după dialecte și monumente vechi, that sîm was an "original" [Rom. "originarie"] (p. 148) ${ }^{29}$, after some other Latinist scholars, like Ion Codru Drăgușanu, had considered it a "classical form" (p. 69). (Sum-a cultured form in Romanian-was registered in the southern part of the Romanic territory, in Calabria, and interpreted as the natural continuation of the corresponding Latin form; see Rohlfs (1968, p. 540).)

III.1. The form sunt, like sum, has been considered a cultured norm, "introduced into the literary language by the Latinist School" (DA 1934, p. 113, s.v. fi); the idea is indeed supported by its occurrences in various texts.

It seems that it was first used, only for the $3^{\text {rd }}$ person plural, indicative present, by Paul Iorgovici (probably), at the beginning of the $18^{\text {th }}$ century, in the same two printed texts. In Calendariu (1794), in Istoria amerii, there are two forms that interest us: the "classical" form sunt (spelled с $\mathbf{8} \mathbf{\text { TT}}$ ): "mijlociri sunt de a repara" [there are means to redress] (p. 30) and the analogical form sunteți (spelled с४нттеци): "de vină sunteți voi" [you are to be blamed], "voi sunteți un moștean bogat" [you are a rich owner] (p. 28), "voi sunteți un om onest" [you are an honest man] (p. 30), "voi sunteți nește oameni” [you are some people] (p. 32), "sunteți a nu ve putea întoarce" [you are in the position of not being able to come back] (p. 33). In Observații de limba rumânescă (Buda, 1799), the number of occurrences for sunt and suntem increases significantly: "Mai toate de cătră frig sunt îmbrăcate cu vesminte" [Due to the cold, most of them are dressed with clothes] (p. 1), "sunt noauo bune au ba" [they are good or not to us] (p. 3), "în limba noastră sunt fundate" [in our language, they are settled] (p. 14), "Cu aceste particule sunt împreunate cuvintele" [With these particles, words get joined] (p. 15), "Vorbele sunt semnele preceptului minții" [Words are the sign of a mind's perception] (p. 21), "cuvintele sunt semnele arbitrarie" [words are arbitrary signs] (p. 21); see, for sunt, p. 18, 23, 24, 25, 26, 29, 30, 34, 37, 73, 74, 77, 79, 80, 81, 82, 88, 89, 90, 92; "Suntem siluiţi a da unui nome mai multe înțelesuri" [We are to give many a significant to a word] (p. 22), "Noi suntem auzitorii legiei" [We are those who hear the law] (p. 90). The form sint, which appears constantly in old texts and in pre-modern texts written with Cyrillic lettres, is used in Observații in four contexts only, most probably due to some "slips" of the typographer, under the pressure of the customary norm of the time: "Cele mute sînt și mai tare la trup" [The mute ones are stronger] (p. 1), "Aceste toate la toți sînt cunoscute" [All these are known to all] (p. 8), "acum sint cu sîrbii" [they are with the Serbians now] (p. 13), "sum, esci, este; sum, es, est; sein; sînt, ești, este” (p. 69).

The verbal form suggested by Paul Iorgovici is registered, as sûnt, by Gheorghie Constantin Roja, in Măiestria ghiovăsirii românești cu litere latinești [The Art of Reading Romanian with Latin Letters], published in Buda, in 1809 (p. 43). It also appears, for the $3^{\text {rd }}$ person plural, indicative present in Cântare despre inceputul și starea de astăzi a românilor [Poem About the Beginnings and the Present State of the Romanians] by I. Theodorovici Nica, printed with Latin letters in Buda, in 1813 (p. 1, 5). It is also used,

\footnotetext{
${ }^{27} \mathrm{DA} 1934$ registers the forms sin, sim (DA 1934, p. 113, s.v. fi) from several old texts, and from certain patois.

${ }^{28}$ According to the modern dialectology, sim, borrowed from Serbian or Bulgarian, can nowadays be found in Meglenoromanian (see Atanasov, 1984, p. 528 and 2002, p. 250) and in Istroromanian (Sîrbu \& Frățilă, 1998, p. 271; Kovačec, 1998, p. 78). It was registered in Dacoromanian as well, although scarcely, in Banat (as a Serbian influence), in Muntenia and in Dobrogea (as a Bulgarian influence). See ALR 1972, h./map 2156.

${ }^{29}$ August Scriban thought that sîm was the direct descendent of a Latin form; in Scriban (1939), s.v. sint, fost, a fi, he wrote: "lat. sìm, sìmus, sìnt [cl. sum, sŭmus, sunt] de unde s-au făcut sîm [azi sînt], sem [apoi sîntem, azi sîntém], set [apoi sînteți, azi sîntéți], sint" [Lat. sìm, sümus, sint [Cl. sum, sümus, sunt] from which there are sîm [nowadays sînt], sem [then sîntem, nowadays sîntém], set [then sînteți, nowadays sîntéți], sînt]. See the same opinion at Fugariu (1983, p. 608, Note b).
} 
with the same morphological function and the same graphic form $(\operatorname{sunt})$, by Vasile Gergely of Csokotis, in Omu de lume [Man of the World], Vienna, 1819 (p. VII, 1, 8, 70).

The form sunt (spelled also sunt) is used, in 1819, by Petru Maior, in the column written with Latin letters and etymological orthography of his programmatic Dialog pentru începutul limbei română, an appendix to Orthographia Romana sive Latino-Valachica, but it corresponds both to the $3^{\text {rd }}$ person plural and the $1^{\text {st }}$ person singular of the verb a fi: "precum si în scripturile lor se vede, nu escu (sủnt) fỏrả indoelă" [as one can see from their texts too, it is not indeed] (p. 54), "doả sunt pareri le invetiaților" [two are the opinions of the scholars] (p. 55), "multe cuvente ... nu sunt in limba latină" [many a word... are not in Latin] (p. 56), "limbile aqueste sunt cuscrite la olaltả, érỏ de limba latinả ... sunt strảinate" [these languages are related to each other, and are estranged... from Latin] (p. 57) ${ }^{30}$.

Alongside of sunt and sunt - that reappeared in the Dialog... in 1825, when Petru Maior republished it as an opening to the Lexicon românesc-latinesc-unguresc-nemțesc-there are, in the dictionary itself, several other occurrences of the same forms: "sünt, șed,u" (p. 2) 31 , "Escu. Macedo-Valachice, sum. V. sünt" (p. 206), "sủntu, a fi, fostu”, "sủntu de faciẻ” [I am here], „sủntu depảrtatu” [I am away], ,sủntu ỉn lỏuntru” [I am inside], ,sủntu intrả quariiva” [I am at someone], „sủntu preste quineva” [I am above someone] (all on p. 686), "nu süntu" [I am not] (p. 687). In passages written with Cyrillic letters, in both texts (Dialog... and Lexicon...), the corresponding forms to sunt and sunt use, without exceptions, a yus (cхNT) or a back yer $(\mathbf{c} \mathbf{k} \mathbf{n T})^{32}$.

The form sunt, this time spelled exclusively without the diacritic sign, appears also in Dicționariul românesc, latinesc și unguresc [The Romanian, Latin and Hungarian Dictionary], printed under the protection of Ioan Bobb (tome II, Cluj, 1823, p. 428-429). Samuil Micu, as well, uses several verbal forms with $u$ without the diacritic sign, in Cartea cătră cler șipopor (Oradea, 1824; sunt, p. 9, 12; see also suntem, p. 14, sunteți, p. 6, 7). Nicolao Maniu Montan (1826) writes sünt (3 pl., p. 25, 26, 41), sunt (p. 41), and süntem (p. 42). Ioan Alexi describes sunt as a form proper to the $1^{\text {st }}$ person singular and the $3^{\text {rd }}$ person plural, in Alexi (1826): "jo sủm vel sủnt" (p. 77), "jo sủm, sủnt, ego sum ..., ei sủnt, illi sunt, elle sủnt, illæ sunt” (p. 81). Finally, Timotei Cipariu uses the form suntu ( $3^{\text {rd }}$ person pl.) in Ecloga (Blaj, 1833, p. 4).

In Wallachia, having published, in 1839, Paul Iorgovici's Observații de limbă rumânească in Curier de ambe sexe $e^{33}$, Ion Heliade Rădulescu adopted-undoubtedly, under the influence of the Banatian scholar ${ }^{34}$-the form sunt ( $3^{\text {rd }}$ person pl., spelled $c 8 n t$, in many an issue of the magazine printed with the so-called "alphabet of transition": II, p. 84, 86, 91, 351, 352, 358, 375; III, p. 169, 190; IV, 31, 33), instead of sint (spelled схнту or csnt). Later on, when the "alphabet of transition" was replaced by the Latin alphabet, and the magazine began to be printed with the latter, the verbal form appeared as sunt (V, p. $2,31,83,245$; VI, p. 85,90 ), still referring to the $3^{\text {rd }}$ person plural of the indicative present of the verb a fi.

After 1860, the graphic form sunt was recommended by Timotei Cipariu's Gramateca limbei române (Bucharest, 1869): “suntu, -su” (I, p. 274) and also by August Treboniu Laurian și Ioan C. Massim's Dicționariul limbei române: "indic. presente: ... su sau sunt sau suntu; in urmarea acestei forme d'in pers. III pl. s'au formatu dupo analogi'a verbeloru de conjugationea III ... suntu, suntemu, sunteti” [indicative present: su or sunt or suntu; following this form of the $3^{\text {rd }}$ person pl., through analogy with the verbs of the $3^{\text {rd }}$ conjugation, there have been formed suntu, suntemu, sunteti] (I, p. 1240) - two normative works that were published under the ægis of the Romanian Academy; moreover, it was presented as a rule in Regulele

\footnotetext{
${ }^{30}$ The references concern the text published as an opening to the Buda Lexiconului. See also the modern edition of the Dialog..., edited by Florea Fugariu (in Maior, 1976).

${ }^{31}$ The form sunt appears, in the same context, in the prospectus of the dictionary of Samuil Micu, printed in Buda, in 1814.

${ }^{32}$ See also Chivu (2000a, p. 431-437).

${ }^{33}$ The edition published in 1839, with the "alphabet of transition", in Curier de ambe sexe (II, no. 6, p. 82-118) would be published again, during the same year, in Curierul românesc (no. 55, 56, 61, 65, 67, 72).

${ }^{34}$ Ivănescu (1980, p. 665) held the same idea, that Ion Heliade Rădulescu had written sunt and suntem under the influence of Paul Iorgovici.
} 
ortografice ale limbei române, adoptate de Ministeriul Instrucțiunii Publice și al Cultelor [Orthographic Rules of the Romanian Language, Approved by the Ministry of the Public Instruction and of Cults] (Bucharest, 1871): "sûntü" (p. 5).

The literary texts from the second half of the $19^{\text {th }}$ century would gradually adopt the orthographic norm of the Academy; and sunt would continue to be the explicit orthographic norm at the beginning of the $20^{\text {th }}$ century as well ${ }^{35}$.

III.2. It results from the above that, like sum (formerly written $\mathbf{c} 8 \mathbf{m}$ ), the verbal form sunt (formerly written с $\mathbf{8} \mathbf{\text { T}}$ ) was introduced into the Romanian writing by Paul Iorgovici, through Calendariul rumânesc from 1794, and through Observații de limba rumânească from 1799, where-judging by the Cyrillic orthographic rules, and also by its specific morphological value-it used to cover a pronunciation similar to that of the Latin form that it was, in fact, reproducing: /sunt/.

After 1800, sunt, written with Latin letters, and in multiple variants (sunt, sûnt, sünt, sünt), appeared constantly in texts signed by Transylvanian and Banatian Illuminists. After 1840, it was adopted, due to the Latinists' influence, by the Wallachian writers, and became, during the second half of the $19^{\text {th }}$ century, due to the general embracing of the Latin alphabet, the official orthographic norm.

Coexisting with sent and sint (sometimes spelled with diacritic signs: sént, sênt, sênt; sint, sînt, sinnt) forms that were used in many texts written and printed with Latin letters (e.g., Elementa lingue DacoRomane sive Valachice, Vienna, 1780; $2^{\text {nd }} \mathrm{ed} ., \mathrm{Buda}, 1805$; and Lexiconul rumânesc, latinesc, unguresc,

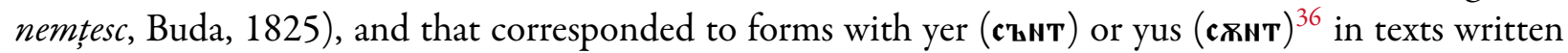

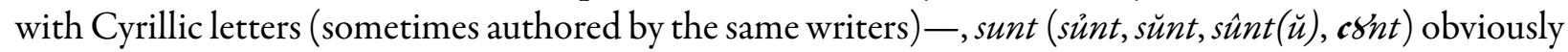
represented, during the entire $19^{\text {th }}$ century, an etymological graphic form, in which $u(\hat{u}, \breve{u}$ or $\hat{u})$ stood for a central vowel $(/ \mathbf{i} /)$.

Ion Heliade Rădulescu was explicit about this pronunciation, in his clarifying notes on the use of the Latin alphabet in the $5^{\text {th }}$ issue of Curier de ambe sexe: "Mai vedem iară că $(u)$ și $(i)$ adesea, înaintea consoanelor nasale $(m)$ și $(n)$, se pronunță pe nas, ca $(8)$ slavon, precum ... sunt ca sânt" [We see also that $(u)$ and $(i)$, before the nasal consonants $(m)$ and $(n)$, are often pronounced through the nose, like the Slavic (8), as ... sunt like sint] (p. VIII). Timotei Cipariu too asserts that sunt spelled with Latin letters is pronounced "cu $u$ oscur ca $\boldsymbol{x}$ " [with a close $u$ like $\boldsymbol{x}$ ] (Cipariu, 1866, p. 148-149). And the authors of the Regule ortografice ale limbei române, adoptate de Ministeriul Instrucțiunii Publice și al Cultelor say that "accentul circumflex $(\wedge)$ pus deasupra vocalelor plenisune [în forme de tipul sûntŭ ] arată că aceste vocale trebuie a se pronunța atunci cu un ton nasal, echivalinte vocalei cirilice $\boldsymbol{x}$ ” [the circumflex accent $(\wedge)$ placed over the voiced vowels [in forms like sûntŭ] shows that these vowels need to be pronounced with a nasal tone, one equivalent to that of the Cyrillic vowel $\mathrm{x}]$ (p. 5).

Under the influence of its graphic form, sunt gradually became, during the first decades of the $20^{\text {th }}$ century, the literary pronunciation as well (/sunt/); nevertheless, it continued to alternate with the etymological form sint /sint/, for a long time ${ }^{37}$.

Used first at the end of the $18^{\text {th }}$ century, in two texts that owe their existence to Paul Iorgovici, the verbal form sunt (spelled $\mathbf{c} 8 \mathbf{N T}$ ) - coexisting with sum (spelled $\mathbf{c} 8 \mathbf{m}$ ) and having the exact morphological value of the Latin sunt ${ }^{38}$ - seems indissolubly connected to the Latin model promoted by the Transylvanian School. At the end of the $18^{\text {th }}$ century and the beginning of the $19^{\text {th }}$ century, suntu (written with Greek letters, and then, in 1813, by Mihail Boiagi, with Latin letters) appears in several Aromanian texts pub-

\footnotetext{
${ }^{35}$ See Regule ortografice, Glosar, Institutul de arte grafice „Carol Göbl”, Bucharest, 1904, p. 14.

${ }^{36}$ One may notice the examples written with Latin letters and re-written-in order to clarify their pronunciation-with Cyrillic letters, in various orthography manuals of the epoch, and in the two columns of Petru Maior's Dialog pentru inceputul limbei română-one written with Cyrillic letters, one with Latin letters-, and in the introduction to the Lexicon from Buda.

${ }^{37}$ In Pușcariu \& Naum (1941, p. 69), the authors state that "in everyday speech, one can hear forms with $\hat{a}(/ \dot{\mathbf{t}} /$, , n.n., G.C.) instead of $u(/ \mathrm{u} /$, n.n., G.C.), namely sânt, sântem, sânteți, sânt”.

${ }^{38}$ The form sum corresponded to the $1^{\text {st }}$ person sg., indicative present, while sunt corresponded to the $3^{\text {rd }}$ person pl.
} 
lished in Vienna, Venetia or in Buda (Boerescu, 2002, p. 136-137). The form suntu, characteristic for Aromanian (Papahagi, 1963, p. 659-660, s.v. hiu) is registered by Constantin Ucuta, in Nea paidagogia, a primer he publishes in 1797 ( $\sigma 8 v \tau$ \&, p. II, 7, 40); then, by Daniil Moscopoleanu, in Eisagogiki didaskalia (= Invățătură introducătoare), from 1802 (p. 3), and by Mihail Boiagi, in Grammatiki romaniki itoi Makedovlahiki, from 1813 (p. 68, 132, 136, 226).

Is it possible that Paul Iorgovici took the form sunt from Latin? Is it possible that he adopted a linguistic feature of the Aromanians he had met in Buda and in Vienna, in his struggle to create a literary norm by making use of some elements that belonged to the historical variants of the Romanian language? (Petru Maior contended, in 1819, in his Orthographia Romana, that the literary language which the Transylvanian Latinists were trying to create "must agree with the nature of the Romanian language and involve all the dialects of this language", p. IV.) Or is it possible that he discovered sunt in one of the local patois spoken in Banat? ${ }^{39}$

Any of the answers suggested above may be true. Evaluating the information existing so far, we are in the position to state that, as in the case of sum, the Transylvanian Latinists may have assumed that suntwhich had been proposed by Paul Iorgovici, following a Latin model-was a "classical" form, preserved by Aromanian and by certain conservative Dacoromanian patois (although sunt $(u)$ doesn't actually correspond to the Latin sunt, but to an accidental phonological evolution: the change of $\dot{\mathrm{t}} /$ from sintu into $/ \mathrm{u} /$, through a regressive vocalic assimilation).

IV. The present analysis argues the idea that sum and sunt-two cultured verbal forms that appeared simultaneously, at the end of the $18^{\text {th }}$ century, in texts related to Paul Iorgovici-knew similar histories and evolutions.

Initially proposed as literary pronunciations shaped after the Latin model, the two verbal forms were soon adopted, but also reinterpreted by the majority of the Transylvanian scholars: thus, they become a common presence in texts written with Latin letters and etymological orthography; later on, they regain the status of literary pronunciations, due to the influence of the writing with the Latin alphabet (given the phonological tradition of the Romanian writing).

The histories of the two cultured verbal forms are also similar in what concerns their relation to certain regional pronunciations that may seem conservative, namely sim and suntu, which were erroneously regarded by the Transylvanian Latinists as reminiscences of some forms inherited from Latin.

[Translated by Adina Chirilă]

\section{Bibliography}

\section{A. Sources}

*** Lexicon românesc, latinesc, unguresc, nemțesc, Buda, 1825.

*** Regule ortografice, Institutul de arte grafice „Carol Göbl”, București, 1904.

*** Regulele ortografice ale limbei române, adoptate de Ministeriul Instrucțiunii Publice și al Cultelor, București, Imprimeria Statului, 1871.

Alexi, I. (1826). Gramatica Daco-Romana sive Valachica, Viennæ.

Bălășescu, N. (1848). Gramatică română pentru seminarii şi clase mai înalte (Grammatica Daco-Romana), Sibiu.

Bobb, I. (1823). Diç̦tionariul românesc-latinesc și unguresc, II, Cluj.

\footnotetext{
${ }^{39}$ One of the authors of the Tratat de dialectologie românească [Treatise of Romanian Dialectology] (Neagoe, 1984, p. 262) finds sunt in Banat, but the same form is present also in patois located in Southern and central Transylvania (see Zdrenghea, 1948, p. 195-197; ALR 1972, hărțile 2156, 2157, 2158). We do not take into consideration the existence of sunt in some isolated areas from Wallachia, Dobrogea, the centre of Moldavia, since, even of ancient character (which is highly improbable), it couldn't have been known by Paul Iorgovici.
} 
Chivu, Gh. (ed.) (2008). Dictionarium Valachico-Latinum, primul dicţionar al limbii române, Editura Academiei Române, București.

Cipariu, T. (1850). Elemente de Grammatică română pentru școlarii începători, București.

Cipariu, T. (1854). Elemente de limba română după dialecte și monumente vechi, Blaj.

Cipariu, T. (1855). Compendiu de Gramateca limbei române, Sibiu.

Cipariu, T. (1866). Principie de limbă și de scriptură, Blaj.

Cipariu, T. (1869/1987, 1876/1992). Gramateca limbei române, Partea I. Analitica, Partea a II-a. Sintetica, București, vol. I, II (ed. modernă de Carmen Pamfil, în T. Cipariu, Opere, I-II, Editura Academiei Române, București)

Cipariu, T. (1972). Jurnal, ed. Maria Protase, Editura Dacia, Cluj-Napoca.

Cipariu, T. (1984). Discursuri, ed. Ștefan Manciulea, Ion Buzași, Editura Dacia, Cluj-Napoca.

Codru I.G. (1848). Rudimentele gramaticei române, București.

Frâncu, T. \& Candrea, G. (1888). Românii din Munții Apuseni (Moții), București.

Fugariu, F. (ed.) (1983). Școala Ardeleană, II, Editura Minerva, București.

Hasdeu, B.P. (1891). Anonymus Lugoshiensis. Cel mai vechi dicționar al limbei române, după manuscriptul din Biblioteca Universității din Pesta, in "Revista pentru istorie, archeologie și filologie”, no. VI, p. 1-48.

Hasdeu, B.P. (1973). Duduca Mamuca. Din memoriile unui studinte, ed. Ion Șeulean, Editura Dacia, Cluj-Napoca.

Hasdeu, B.P. (2003). Opere, IV. Dramaturgia, ed. Stancu Ilin, I. Oprișan, București.

Heliade Rădulescu, I. (1828/1980). Gramatică românească, Sibiu; ed. Valeria Guțu Romalo, Editura Eminescu, București.

Iorgovici, P. (1799/1979). Observații de limba rumânească, Buda; ed. Doina Bogdan-Dascălu, Crișu Dascălu, Editura Facla, Timișoara.

Laurian, A.T. (2002). Tentamen criticum, ed. Katalin Dumitrașcu, Editura Universitaria, Craiova.

Laurian, A.T., Massim, I.C. (1871). Dicționarul limbei române, [I], București.

Maior, P. (1819). Orthographia Romana sive Latino-Valachica, Buda.

Maior, P. (1976). Scrieri, II, ediție Florea Fugariu, Editura Minerva, București.

Maller, P. (1832). Grammatica Hungarico-Valachica, Buda.

Maller Câmpeanu, P. (1848). Grammatică românească, Iași.

Maniu Montan, N. (1826). Orthoepia Latina, Latino-Valachica, Hungarica, Germanica et Serbo-Valachica, Cibinii.

Micu, S. (1824). Cartea cătră cler și popor, Oradea.

Micu, S. \& Șincai, Gh. (1780, 1805/1980). Elementa lingue Daco-Romane sive Valachicae, Viena, Buda; ed. Mircea Zdrenghea, Editura Dacia, Cluj-Napoca.

Munteanu, G. (1860). Gramatica română pentru clasile gimnasiali inferiori, [I]. Partea etimologică, Brașov.

Seulescu, G. (1833). Grammatică românească, Iași.

\section{B. References}

ALR 1972 = Atlasul lingvistic român, Serie nouă, VII. Verbul, [București], 1972.

Atanasov, P. (1984). Meglenoromâna, in Tratat de dialectologie românească, Scrisul Românesc, Craiova, p. 476-550.

Atanasov, P. (2002). Meglenoromâna astăzi, [București].

Avram, M. (1992a). Cultisme adverbiale cu sufixul -e în limba română, in Studii de morfologie a limbii române, Editura Academiei Române, București, 2005, p. 234-250.

Avram, M. (1992b). Din istoria formațiilor participiale moderne in -ând, -ind, in Studii de morfologie a limbii române, Editura Academiei Române, București, 2005, p. 205-217.

Boerescu, P. (2002). Din istoria formelor grafice sunt, sint, sent şi a variantelor acestora cu semne diacritice, in "Limba română", vol. LI, no. 4-6, p. 133-141.

Chivu, Gh. (2000a). Este sunt o simplă grafie latinizantă?, in “Limba română”, vol. XLIX, no. 3, p. 434-435.

Chivu, Gh. (2000b). Grafii etimologizante în scrisul chirilic românesc din jurul anului 1800, in Ion Coteanu. In memoriam, Editura Universitaria, Craiova, p. 100-105.

Chivu, Gh. (2002a). Cei doi excesuri a amerii - o «istoriolă» romantică într-un calendar de la sfârşitul secolului al XVIII-lea, in "Limbă și literatură", vol. I-II, p. 91-98.

Chivu, Gh. (2002b). Un experiment literar și lingvistic la sfârșitul secolului al XVIII-lea, in "Comunicările Hyperion”, Filologie, no. 11, p. 149-158.

Chivu, Gh. (2015). Normă ideală - normă reală în scrisul literar de la sfârșitul veacului al XVIII-lea. Infinitivul lung, in: Variația lingvistică: Probleme actuale, I. Gramatică, Istoria limbii române, fllologie, dialectologie, Editura Universității din București, p. $183-190$.

DA 1934 = Dicționarul limbii române, tomul II, partea I, F-I, București, 1934.

Gheție, I. (1967). I. Heliade Rădulescu și selecția cuvintelor românești «clasice», in “Limba română”, vol. XVI, no. 3, p. 221 -223.

Gheție, I. \& Teodorescu, M. (1965). Asupra desinenței -u a pers. 3 pl. a imperfectului indicativ, in "Studii și cercetări lingvistice", vol. XVI, no. 1, p. 87-101.

Gheție, I. \& Teodorescu, M. (1966). Asupra desinenței - u a pers. 3 pl. a indicativului imperfect, in “Studii și cercetări lingvistice”, vol. XVII, no. 2, p. 175-183. 
Ivănescu, G. (1944-1945). Probleme capitale ale vechii române literare, in "Buletinul Institutului de Filologie Română «Alexandru Philippide»", vol. XI-XII.

Ivănescu, G. (1980). Istoria limbii române, Editura Junimea, Iași.

Kovačec, A. (1998). Istrorumunjsko-hrvatski rječnik (s gramatikom, tekstovim), Pula.

MDA 2002 = Micul dicționar academic, II, D-H, Editura Univers Enciclopedic, București, 2002.

Neagoe, V. (1984). Subdialectul bănățean în Tratat de dialectologie românească, Scrisul Românesc, Craiova, p. 240-284.

Nedelcu, I. (2013). Particularități sintactice ale limbii române în context romanic. Infinitivul, Editura Muzeului Național al Literaturii Române, [București].

Papahagi, T. (1963). Dicționarul dialectului aromân, general și etimologic, Editura Academiei Române, [București].

Pușcariu, S. \& Naum, T. (1941). Îndreptar și vocabular ortografic, ediția a III-a, revăzută și completată, Editura Cartea Românească, București.

Rohlfs, G. (1968). Grammatica storica della lingua italiana e dei suoi dialetit, [II], Morfologia, [Torino].

Scriban, A. (1939). Dicționaru limbii românești, Institutul de arte grafice "Presa Bună”, Iași.

Sîrbu, R. \& Frățilă, V. (1998). Dialectul istroromân, Texte și glosar, Editura Amarcord, Timișoara.

Tiktin, H. (1906). Rumänisch-Deutsches Wörterbuch, II, Bukarest.

Ursu, N.A. (1963). Un calendar istoric-literar publicat de Paul Iorgovici, in "Limba română", vol. XII, no. 3, p. $283-291$.

Zdrenghea, M. (1948). Analogii in conjugarea verbului auxiliar a fi, in "Dacoromania”, no. XI, p. 195-197. 